\title{
What Degree Is Necessary to Lead? ARL Directors' Perceptions
}

\section{Russell Michalak, Monica D.T. Rysavy, and Trevor A. Dawes}

In 2018, after a failed search for the Executive Director of the American Library Association (ALA), ALA members put forth a ballot initiative to determine whether the educational requirements for the position should be modified, in part, to expand the potential applicant pool. With this research, the authors examined if current ARL administrators hold an MLS/MLIS and whether current ARL administrators felt it was necessary for library administrators to hold an MLS/MLIS. Additionally, the researchers examined ARL administrators' perspectives regarding whether it was necessary for them to earn additional degrees to achieve their highest library administrative position, and whether they felt their degrees prepared them to be successful in the position that they currently hold.

\section{Introduction}

According to an ALA member demographics survey conducted in 2017, (with a 74 percent response rate), 61.7 percent of the membership hold an MLS degree and 38.3 percent did not. ${ }^{1}$ It is worth noting that these results do not indicate the respondents' career. Some members of ALA are not librarians and may have no intention of working as a librarian. For example, a faculty member who is presenting at ACRL could join ALA - the parent organization - for the year with no intention of becoming a librarian but may choose to join for the benefits afforded by an ALA membership. The diversity of members' backgrounds is an important context through which to consider the results of any membership vote. This issue was put to a vote during ALA's recent search for a new executive director to determine whether the educational requirements needed to be modified to expand the potential applicant pool. Specifically, the ALA executive board sought to determine whether ALA membership believed that the educational requirement of an MLIS should be required or preferred qualification. The referendum resulted in more than half of the current membership $(62.6 \%, \mathrm{n}=6,515)$ voting for $M L S$ required and the remainder $(37.4 \%, \mathrm{n}=3,890)$ indicating MLS preferred. The population polled for the referendum consisted of the 10,405 active members at the time of the referendum. However, as ALA bylaws require that 25 percent of the membership must vote for a vote to be considered valid, this referendum did not pass - only 21 percent of the membership participated.

\footnotetext{
${ }^{*}$ Russell Michalak is Director of Library, Archives, E Learning Center at Goldey Beacom College, email: michalr@gbc.edu; Monica D.T. Rysavy is the Director of Institutional Research E Training at Goldey Beacom College, email: rysavym@gbc.edu; and Trevor A. Dawes is Vice Provost for Libraries and Museums at the University of Delaware Library, email: tadawes@udel.edu. (2019 Russell Michalak, Monica D.T. Rysavy, and Trevor A. Dawes, Attribution-NonCommercial (http://creativecommons.org/licenses/by-nc/4.0/) CC BY-NC.
} 
In this study, the authors examined the following research questions:

- Research Question 1: Do ARL administrators typically hold an MLS/MLIS?

- Research Question 2: Do ARL administrators feel that it is necessary for library administrators to hold an MLS/MLIS?

- Research Question 3: How does RQ2 compare to ARL administrators' level of satisfaction regarding the recent ALA member demographics survey?

- Research Question 4: Do ARL administrators believe it was necessary for them to earn additional degrees for them to achieve their highest library administrator position?

- Research Question 5: Do ARL administrators believe their degrees prepared them to be successful in the position they currently hold?

Minimal research has been published on ARL directors' perceptions regarding the need for library administrators to hold an MLIS/MLS degree since Hernon, Powell, and Young's 2001 study (also published in College $\mathcal{E}$ Research Libraries). Therefore, with this work we sought to update previous research with our current survey results in light of conversations surrounding the recent ALA executive director search regarding the need of the MLIS/MLS degree for library administrators.

\section{Literature Review}

To provide context for this study, the following literature review summarizes the past work of authors who explored library director credentials as early as the 1930s to present day.

\section{Library Director Credentials - Historical Perspectives (Pre-1990)}

Prior to 1990, librarians have debated the necessity of attaining a master's degree to lead an academic library versus attaining a second master's degree or doctorates (PhD, JD, or EdD). Studies reported and discussed the level of education necessary for those individuals who lead academic libraries. Researchers have sought to ascertain if those who lead libraries need solely an MLS/MLIS or if another degree provides the necessary skills to lead an academic library. Cohn conducted one of the earliest and most comprehensive studies in which he tracked ARL directors' education from 1933 to 1973. He noted that in 1933 there were 36 ARL libraries and at the time of appointment to an ARL director position only one (or 1.5\%) of the ARL directors had a BA plus an MLS. In 1970-1973, 16 (43\%) of the ARL directors had a BA and MLS. ${ }^{2}$ Cohn pointed out that, by 1976, the MLS was required to lead an ARL library. ${ }^{3}$

The need for an advanced degree (second master's or doctorate) was also under discussion during this time and was not a requirement by universities in the past to lead a research library. Parsons examined ARL directors' academic preparation in 1958 and 1973. The number of ARL directors who had earned a doctorate decreased by 8 percent from 1958 to 1973. In 1958, 12 ARL directors held a PhD in library science, while in 1973, 11 ARL directors held this title. ${ }^{4}$ In contrast, the number of ARL directors with a subject master's degree increased by 40 percent between 1958 and 1973. During the same time period, the number of ARL directors with an MLS degree increased by 533 percent. $^{5}$

Researchers have examined if ARL directors hold an advanced degree beyond the MLS. Of those who led research-focused libraries, the number of ARL directors $(n=254)$ with a non-library-related doctorate declined between 1933 and $1973 .{ }^{6}$ The number of library science doctorate degrees awarded significantly increased during the time periods Cohn compared. Cohn found that, despite the large increase in doctoral degrees awarded during 
this time period, the librarians who held doctorates chose not to follow the ARL administrative pattern. ${ }^{7}$

In the 1980s, researchers examined gender and its relation to career advancement in higher education administration, specifically in the field of librarianship. Moran sought to identify the academic credentials that academic library administrators attained to advance. She tracked the 10-year career trajectory of assistant and associate academic library directors $(n=444)$ from 1970 to 1980 . The data revealed that the men who held academic library administration positions had acquired a professional credential (library degree) and relocated if necessary. The career advancement of women to the same administrative levels as the men in the same study was found to relate to internal promotions; the degree mattered less. ${ }^{8}$ Moran's seminal study revealed that men who held advanced degrees ${ }^{9}$ were more likely to attain a director position than women who held advanced degrees -64 percent of the men in administrative positions held doctorates, while 25 percent of women held the same degree. ${ }^{10}$

At the same time, Mech compared the educational background of small-college library directors in the Midwest to university library directors. Mech reported that 97 percent of the library directors he surveyed had attained a library degree - an almost universal job requirement at any size college or university in the 1980s. ${ }^{11}$ Researchers noticed the job market tightened in libraries during the 1980s as many displaced, unemployed, or failed academics from other disciplines moved into libraries. ${ }^{12}$ Consequently, the competition stiffened with more candidates applying for director-level positions in academic libraries. ${ }^{13}$

Researchers have audited job listings in library trade journals to determine if job requirements for nonadministrative librarians and library directors were different. Olsgaard and Olsgaard audited job postings for all librarians (nondirector and director) in Library Journal and College \& Research Libraries News from 1970 to 1979. According to the researchers, in 1975 the ACRL Board of Directors "set the basic educational requirement for academic librarians as the MLS," 14 but most job postings for academic libraries set educational requirements above the MLS. Their survey revealed, "The post-MLS requirements for both nondirector categories and for university director positions rose steadily until 1976, and have declined since then. It was also determined that this rise and decline was statistically significant and not due to chance."15

Olsgaard and Olsgaard compared previous studies' results to their results. They discovered their findings were comparable to the results in Parsons ${ }^{16}$, Cohn ${ }^{17}$, and Metz. ${ }^{18}$ However, there was a high degree of difference between their study and White and Momenee ${ }^{19}$ due to the small sample size. To provide current context for this study, library director credentials from 1990 to present day were also reviewed.

\section{Library Director Credentials - Current Perspectives (1990-Present Day)}

Since 1990, researchers and library practitioners continue to examine the level of education (master's in library science, second master's, and/or doctorate) of senior library administrators. Hatcher, for example, compared the level of education needed to lead academic libraries granularly through the lens of gender as a follow-up to previous studies. ${ }^{20}$ In her study, she studied the succession plans of academic library directors $(n=21)$ who belonged to the Council of State University Libraries (COSUL). All respondents had an MLS degree, 10 had earned a subject master of science, and 5 (or 23\%) had a doctorate. ${ }^{21}$ As Hatcher examined the data more granularly, she reported that more men than women had a subject master's (men, $\mathrm{n}=10$; women, $\mathrm{n}=0$ ); however, it was only a slight increase for men versus women who held a doctorate. (men, $\mathrm{n}=3$; 
women, $\mathrm{n}=2){ }^{22}$ According to Hatcher, women had more success being hired as a library director as an external candidate in non-ARL public libraries; alternatively, men had more success being hired as a library director when they relocated geographically. Having a library degree was not a factor for either men or women to be hired as it was in Moran's seminal study 14 years earlier. ${ }^{23}$

Similarly, McCracken examined librarians' academic credentials at small academic libraries through the lens of gender. He found that the number of library directors at small colleges who held advanced degrees (second master's or doctorate) increased by the year 2000. He reported that 20 percent of the library directors $(n=80)$ who responded to his study held a doctorate and 40 percent held a second master's degree. ${ }^{24}$ When McCracken categorized library directors by gender and education, he found that more men $(n=11)$ than women $(n=5)$ held PhDs. This was consistent for directors who held a second master's degree, ${ }^{25}$ more men $(n=$ $20)$ held a second master's degree than women $(n=11)$. These results compare closely with those found in O'Keeffe's 1996 survey of midwestern Baccalaureate I and II schools. ${ }^{26}$

For some library directors, they deem attaining a second master's degree or doctorate prior to becoming a library director unnecessary. ${ }^{27}$ In 2011, Huisman reported that 80 percent of the Big 10 library directors did not have a doctorate. ${ }^{28}$ She argued that a doctorate beyond the library degree should not be sought for "salary, promotion, or job pressure, not even the prestige of having the title or having peer equality"; instead, for most individuals, earning a second master's or doctorate "is for pure personal incentive." 29

Researchers reviewed job postings to determine if what universities required in their job competencies was what they advertised for in their job posting. Aufderhaar audited job advertisements placed in 1990 in American Libraries. Compared to previous studies conducted, the number of positions requesting additional advanced degrees (subject master's and doctorate) increased. Moreover, 57.6 percent of the positions advertised in that particular magazine were reported to have been filled by individuals who held the requested advanced degrees. ${ }^{30}$ In another study conducted 10 years later for ARL, Blixrud, who surveyed 111 member institutions who belonged to ARL institutions, revealed that 44 percent of the libraries did not require the MLS for all librarian positions. ${ }^{31}$

Hernon et al. audited classified position announcements and interviewed ARL directors to determine to what extent employers value the MLS as a job requirement when hiring potential library directors. In 2001, Hernon et al. noted employers listed the MLS from an ALAaccredited institution as a job requirement. ${ }^{32}$ Employers listed additional degrees such as a second master's degree or a doctorate as preferred. ${ }^{33}$ They interviewed ARL directors without faculty rank and found that the MLS degree was sufficient as the basic degree requirement to administer an ARL library. ${ }^{34}$

Library administrators' perspectives regarding the value of doctorate degrees for library leadership varied. One director forecast that, as more directors become deans, having a doctorate would be one way to earn a seat at the table with other university deans. ${ }^{35}$ However, the director stated, "'Earning a doctorate does not give a person an understanding of how research is done in all disciplines."'”36

Hernon et al. argued that requiring a doctorate could limit the hiring pool in the future. They shared that one director "suspected that the doctorate has not become a universal requirement, as was once expected, in part because it would reduce the size of the pool of candidates too much." ${ }^{137}$ In 2010, Lewis discussed the mismatch problem, citing Gladwell, who "argues that the predictors most of us use in hiring do not match the skills that will be required to do 
the job." ${ }^{38}$ Therefore, Lewis argued that one way for academic librarians to solve the mismatch problem would be to expand the talent pool by hiring professionals without an MLS. ${ }^{39} \mathrm{He}$ stated, "The change in the balance of staff will change this at least to some degree and could require a reworking of the way academic libraries are managed." 40

Some librarians argued that a library degree did not provide librarians the skill set to lead an academic library. In 2013, Farrell stated, "[A] university education, regardless of profession [librarianship], typically does not focus on management or leadership"; ${ }^{41}$ instead, for many librarians, the skill set needed to lead an academic library will be learned after library school through mentorship, associations, and continuing education. ${ }^{42}$ Smit designed an onboarding program that teaches newly hired staff members (none of whom have a formal library degree) the values and philosophies of librarianship that have been traditionally taught in ALA-accredited library schools. Since scholarly communication workflows change so rapidly, there is a need for "lifelong learning on the job" 43 instead of formalized library school.

Programs supported by academic libraries, like the CLIR postdoctoral fellowship, are designed to introduce individuals with $\mathrm{PhDs}$ in other fields to the career of librarianship through socialization and acculturation. Programs like these infuse new talent into academic libraries. CLIR fellows $(n=11,50 \%)$, for example, were exposed to a variety of library-related topics, including library administration. ${ }^{44}$

\section{Methodology}

\section{Background}

The idea for this research began with conversations among the researchers after one researcher (Dawes) shared a blog post (see figure 1) titled I have an MLS, do you? Do you need it?

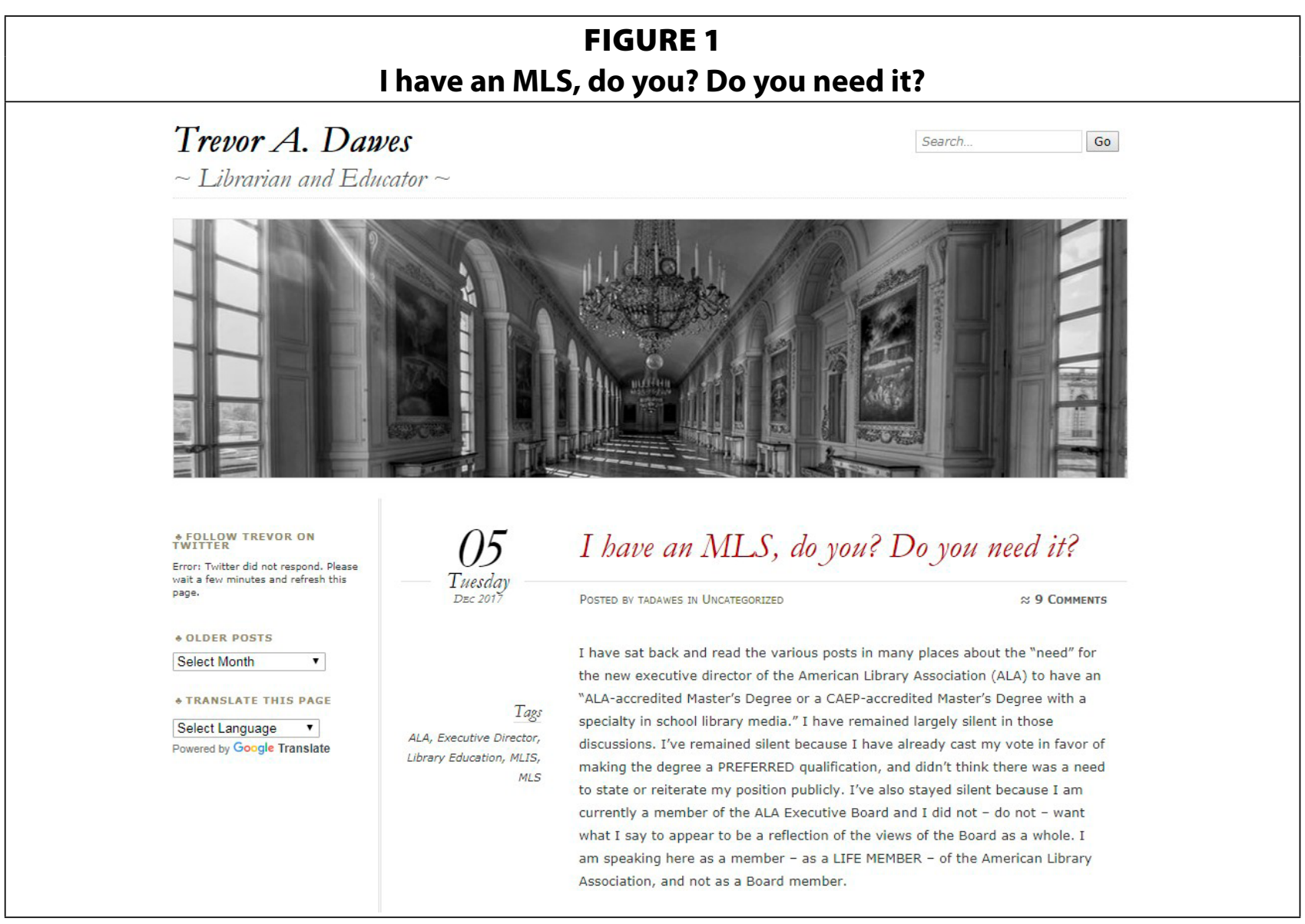




\section{Trevor A. Dawes' Blog Post}

Dawes' post commented on the previously mentioned ALA executive director search controversy, specifically, whether the MLS should be a preferred or required credential. In the conversations that followed, the research team designed an 11-question survey (see appendix) with the goal of learning current ARL directors' perceptions and expectations regarding degree qualifications for academic library directors. Furthermore, ARL directors were asked to consider a variety of hiring factors - from years of experience to number of peer-reviewed publications - and to weigh the level of importance they attributed to these factors when considering candidates for employment as a library director or other senior library administrator position (5-point Likert scale: Extremely important to Not at all important).

The survey was deployed using Qualtrics, an online survey tool, to all 124 Association of Research (ARL) directors included on the ARL listserv at the time of distribution. The survey was deployed on January 29, 2018; the survey was open for approximately one month with one reminder. The survey design included multiple-choice, Likert scale, and open-ended questions. Of the 124 directors invited, 1 invitation bounced, 79 responded, yielding a response rate of 64 percent.

\section{Statement on Ethics and Conflict of Interest}

The research was conducted in adherence to the guidelines of the U.S. Department of Health \& Human Services, and ethics approval was sought and granted by the hosting college's Institutional Review Board (IRB). Participation in this research was strictly voluntary. To meet IRB requirements regarding anonymity, participating students' names were coded with pseudonyms, which were used throughout this study. The codebook was secured in a password-protected file to which only the researchers had access. There were no conflicts of interest in this study.

\section{Results and Analysis}

ARL library administrators were asked in RQ1, Please select the degrees that you hold and indicate the institution(s) where you earned your degree(s). (Select all that apply to you). Of the 79 ARL administrators who responded to the survey, 86.08 percent $(n=68)$ self-reported that they held an MLIS/MLS degree as illustrated in table 1.

The results indicate that the clear majority of current library administrators at ARL institutions hold an MLIS or MLS degree, yet slightly less than half of these administrators believe that it's necessary for library directors or other senior library administrators to hold the same degree. This begs the question: why the disparity? These directors valued the degree at some point since they obtained it in the first place, yet they do not feel their counterparts ought to hold the same degree to lead.

ARL administrators were asked for RQ2, Do you think that it is necessary for a library director or other senior library administrator (such as Dean, Vice

\begin{tabular}{|l|c|c|}
\hline \multicolumn{3}{|c|}{ TABLE 1} \\
Degrees Held by ARL Directors in 2017 \\
\hline \multicolumn{1}{|c|}{ Degree } & $\%$ & Count \\
\hline BA/BS & $94.94 \%$ & 75 \\
\hline MLIS/MLS & $86.08 \%$ & 68 \\
\hline $\begin{array}{l}\text { Master's degree(s) in } \\
\text { nonlibrary field(s) }\end{array}$ & $58.23 \%$ & 46 \\
\hline JD & $3.80 \%$ & 3 \\
\hline MD & $1.27 \%$ & 1 \\
\hline PhD & $27.85 \%$ & 22 \\
\hline EdD & $3.80 \%$ & 3 \\
\hline DBA & $0.00 \%$ & 0 \\
\hline Other (please describe) & $3.80 \%$ & 3 \\
\hline
\end{tabular}


Provost, Associate Vice Provost) to hold an MLS or MLIS degree? Of the 79 ARL administrators who responded to the survey, slightly less than half $(41.77 \%$; $n=33)$ indicated Definitely yes or Probably yes as illustrated in table 2.

ARL administrators who responded Definitely yes or Probably yes regarding the need for the degree were passionate about their reasons for feeling so. One director commented:

So often the knowledge needed to administer a library is underestimated. Faculty believe that

\begin{tabular}{|l|c|c|}
\hline \multicolumn{3}{|c|}{ TABLE 2} \\
ARL Directors' Perceptions \\
Regarding the Need for an MLS or \\
MLIS for Library Administration \\
\hline Answer & $\%$ & Count \\
\hline Definitely yes & $18.99 \%$ & 15 \\
\hline Probably yes & $22.78 \%$ & 18 \\
\hline Might or might not & $25.32 \%$ & 20 \\
\hline Probably not & $16.46 \%$ & 13 \\
\hline Definitely not & $16.46 \%$ & 13 \\
\hline Total & $\mathbf{1 0 0} \%$ & $\mathbf{7 9}$ \\
\hline
\end{tabular}
since that have done research they know how a library works and quite often feel they can walk into a leadership position. Administering a library doesn't necessarily mean you have to have all technical knowledge but you must be able to ask the right questions and fully determine with the information gathered effectiveness and efficiency. With that said, I'm willing to say however that if leadership does not have a library degree they should at least have significant experience with library operations and collection development.

Another director agreed regarding the importance of an MLIS program; he commented:

The courses taught in MLIS programs provide a comprehensive overview of libraries and librarianship that is necessary in order for library directors to have a deep understanding of the work that's done. When directors are appointed who don't have an MLIS, they face a steep learning curve and end up trying approaches that have failed to work or duplicating efforts to deal with challenging issues. This slows overall progress for libraries and deflects attention from actually doing something about the problems that exist to educating the non-MLIS holders.

Another director vehemently declared his support for a dyed-in-the-wool librarian as leader:

We have had this discussion for years. I think this is insane. Only librarians would diminish their degree. You need an MD and a JD to practice medicine or law. If you want to be a physicians' assistant or paralegal (which is great), then you don't need those degrees. I am so happy that the Librarian of Congress is actually a librarian! How radical.

Still another director pointed out that holding an MLS/MLIS can be a matter of trust for directors and their staff. That person stated, "I think the MLS helps you understand the culture and the theories that scaffold libraries. It may not be the only degree you need, but I think it is a good base (or addition) to any other graduate degrees you may hold."

Other library administrators pointed out that the MLIS/MLS credential is critical for maintaining a level of professionalism with the career of librarianship. As one noted: 
By suggesting that a librarian at whatever level does not need the professional degree, we are devaluing and de-professionalizing librarianship. We are saying that librarianship does not carry the same educational, professional, and intellectual requirements as those professions, and we are saying implicitly that librarianship is not really a profession.

Another director shared that not having the degree may minimize library directors' ability to make strategic decisions, stating, "My experience is that senior library leaders who do NOT have an MLS or MLIS (or an appreciation for the development or knowledge gained from the degrees) disparage the professional degrees. This disparagement sometimes leads to bad strategic decisions or decisions outside the broad direction libraries are going."

In contrast, library directors who responded Probably not or Definitely not (regarding the need for the MLIS/MLS degree) felt that the time has passed for the degree to be considered a prerequisite to leading a library. Some felt that particularly given the time that has passed for them since achieving their MLS/MLIS degree and when they became a library director that the skills they obtained during the degree were no longer relevant. Specifically, one director stated:

As someone who has been a librarian for more than 40 years, I don't think that the degree I earned more than four decades ago should be the qualification for my current directorship. Work experience and other professional training (e.g., multiple degrees) are far more meaningful in terms of performing effectively as a library director.

Another director echoed these comments, adding, "A degree is only one indicator of knowledge and experience appropriate for a leadership position. What matters is the knowledge and the experience, not where or how it was obtained. Let's not return to 14th century guild practices."

Additionally, as another library director stated that current advanced degrees were more applicable and relevant to a leadership role than the many years ago earned MLS/MLIS. "My MLIS training (of nearly 25 years ago) did not provide me with any of the skills that I consider to be essential in my role as the library director. Rather I had to go back and get an MBA and a doctorate in higher education administration."

Ultimately, those library directors who felt that an MLIS/MLS degree was not necessary to lead a library placed more importance on practical management skills than foundational library skills. For example, one director commented, “A good CEO doesn't [necessarily] understand the nuts and bolts of the company they lead. Hiring the right people and listening to them, their experience and leadership skills [allow] them to be successful." Another director stated, "Significant experience in and a deep understanding of academic and research libraries are far more important than the MLS. The MLS as a credential has limited value for most of the work performed in research libraries today."

Perhaps the strongest support for not holding the credential came from this director who commented:

Depending on how the institution is structured, the director/dean role is focused on strategy for the organization and overall oversight of administrative affairs. 
True, someone without an MLS might not have the grounding in fundamentals/ foundations of the profession, but they should have grounding in the academy and the work of research, teaching, learning that libraries support. The Admin portfolio is aided by experience there, too. By the time someone reaches that level of experience, the MLS is irrelevant. There have been many successful director/ deans who came from within the academy sans MLS. Dean/Vice Provost is a senior university leadership position and the person's training should be aimed towards university leadership, not just libraries. My MLIS training (of nearly 25 years ago) did not provide me with any of the skills that I consider to be essential in my role as the library director.

ARL administrators' responses regarding their expectations of the need for library administrators to hold an MLIS/MLS (RQ3) were compared to their level of satisfaction regarding the recent ALA member demographics survey. (According to a recent ALA member demographics survey, $61.7 \%$ of ALA members have an MLS degree and $38.3 \%$ do not. Please indicate how satisfied you are with this.)

Of the 79 ARL administrators who responded to the survey, nearly one-third $(30.4 \% ; \mathrm{n}=24)$ indicated that they were Extremely satisfied or Somewhat satisfied regarding the recent ALA member demographics survey as illustrated in table 3 .

A chi-square test of independence was performed to examine the relationship between ARL administrators' satisfaction with the results from the ALA survey about the need for an MLIS degree and whether ARL

\begin{tabular}{|l|c|c|}
\hline \multicolumn{3}{|c|}{ TABLE 3 } \\
\begin{tabular}{|l|c|} 
ARL Administrators' Satisfaction with ALA \\
Survey Question about MLS Degree
\end{tabular} \\
\hline Answer & Count & $\%$ \\
\hline Extremely satisfied & 9 & $11.4 \%$ \\
\hline Somewhat satisfied & 15 & $19.0 \%$ \\
\hline Neither satisfied nor dissatisfied & 50 & $63.3 \%$ \\
\hline Somewhat dissatisfied & 5 & $6.3 \%$ \\
\hline Extremely dissatisfied & 0 & $0.0 \%$ \\
\hline Total & $\mathbf{7 9}$ & $\mathbf{1 0 0 . 0 \%}$ \\
\hline
\end{tabular}
administrators felt that it was necessary for a library director or other senior library administrator to hold an MLIS or MLS degree. The relation between these variables was significant, $X^{2}(12, N=79)=29.5, p<.05$. ARL administrators who were Somewhat satisfied with the ALA survey were more likely to select Probably yes regarding the need for the credential.

Overall, of the 79 ARL administrators who responded to the question (RQ4) "Do ARL administrators believe it was necessary for them to earn additional degrees for them to achieve their highest library administrator position?" 41 percent $(n=33)$ indicated Definitely yes or Probably yes while approximately one-third, 32 percent $(n=26)$ indicated Probably not or Definitely not, as illustrated in figure 2. Of the 79 ARL administrators who responded, 86 percent $(n=68)$ individuals self-reported that they held an MLIS or MLS degree and 32 of the $68(47.06 \%)$ indicated Definitely yes or Probably yes. Nearly 30 percent $(n=19)$ of ARL directors who self-reported that they held an MLIS/MLS indicated Probably not or Definitely not in regard to this question.

Overall, of the 79 ARL Directors who responded to the question (RQ5), "Do ARL administrators believe their degrees prepared them to be successful in the position they currently hold?" the clear majority $(92.4 \%$; $=73)$ indicated Definitely yes or Probably yes. Only two ARL directors disagreed (2.5\%) by indicating Probably not, as illustrated in figure 3. 

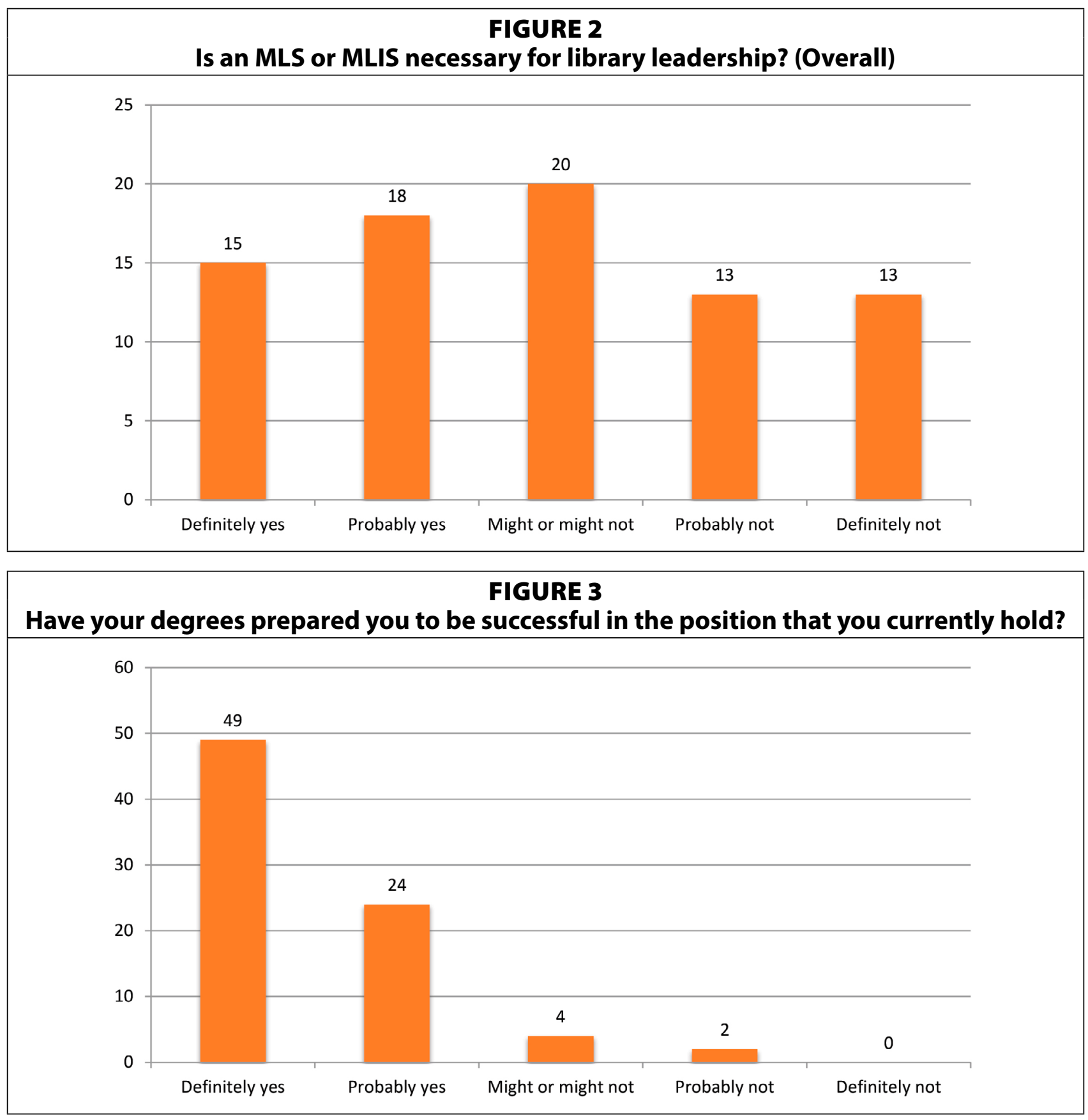

\section{Limitations}

This research is based on the opinions of a very specific group: the 79 ARL directors who responded to this survey. Therefore, the opinions and beliefs shared by this group are not necessarily representative of all academic library directors. Furthermore, the opinions shared in this study are solely those of individuals in director-level (or higher) positions and does not represent the opinions of the majority of the individuals who staff academic libraries. In addition, this research does not represent the opinions of library leadership in public libraries.

It is important to note that the question asking individuals to "Please select the degrees that you hold and indicate the institution(s) where you earned your degree(s)" was a selfreport question that asked individuals to select all that apply to you so it is possible that some individuals did not select that they held an MLIS or MLS because they selected only their 
highest (or lowest) degree. Also, individuals were not asked to indicate the concentration or focus of degrees listed that were not an MLIS/MLS.

\section{Future Research}

Future research could include expanding the population surveyed to include directors at non-ARL institutions and employees of academic libraries of all sizes. This survey could also be deployed to public libraries. Furthermore, in future research, we plan to revise the survey question that asked individuals to report their degrees so that the expectation of selecting all the degrees held will be clearer. Furthermore, future research will include analysis of other data points gathered from the survey (see appendix) but not included in this article (such as hiring factors, ethnicity, age, and gender).

\section{Conclusion}

In conclusion, in the 45 years since Cohn's seminal work studying the degrees that ARL directors held, the number of ARL directors self-reporting that they held this degree has doubled from 43 percent in 1973 to 86.05 percent in 2018. However, with this study, we introduced another perspective that we found lacking in the literature: whether current library directors perceive the MLS/MLIS degree as necessary for those holding library director or other senior library administrative roles. The current leadership of ARL libraries are those who are primarily making the decisions about who will next lead the ARL libraries. If the current leadership believes the MLS/MLIS is necessary to effectively hold a director or similar leadership role, then likely the next cohort of ARL directors will hold the degree. If they don't feel the degree is necessary, then it is likely that we will see fewer ARL directors holding the degree and perhaps more directors holding alternative degrees such as the PhD, DBA, or EdD.

As a research team, given recent conversations about whether the MLIS/MLS degree should be a requirement or a preferred job qualification, we anticipated that many of the current ARL directors would no longer feel that the degree was necessary for library leadership. We were encouraged to learn that, while approximately one third of ARL directors did not perceive the degree as necessary, approximately 42 percent did. However, this near equality in perceptions leads us to believe that this conversation will continue until it potentially reaches a tipping point of perceived degree necessity, likely sooner than the 45 years since Cohn's study. 


\section{APPENDIX}

1. According to a recent ALA member demographics survey, 61.7 percent of ALA members have an MLS degree and 38.3 percent do not. Please indicate how satisfied you are with this.

$\square \quad$ Extremely satisfied

$\square$ Somewhat satisfied

$\square \quad$ Neither satisfied nor dissatisfied

$\square$ Somewhat dissatisfied

$\square \quad$ Extremely dissatisfied

2. Do you think that it is necessary for a library director or other senior library administrator (such as Dean, Vice Provost, Associate Vice Provost) to hold an MLS or MLIS degree?

$\square$ Definitely yes

$\square$ Probably yes

$\square$ Might or might not

$\square$ Probably not

$\square$ Definitely not

3. Why or Why not? Please describe why you responded the way you did in the previous question.

4. Please indicate the level of importance you place on the following hiring factors for a library director or other senior library administrator position.

5. Age
20-24
25-34
35-44
$\square \quad 45-54$
55-64
$\square \quad 65$ and over

6. Gender

$\square \quad$ Male

$\square \quad$ Female

$\square \quad$ Prefer to self-describe:

7. Ethnicity

$\square$ Hispanic

$\square$ American Indian or Alaska Native

$\square$ Black or African American

$\square$ Asian American or APAI

$\square \quad$ White

$\square \quad$ Two or more races

8. Please select the degrees that you hold and indicate the institution(s) where you earned your degree(s). (Select all that apply to you.)

$\square$ BA/BS

$\square$ MLIS/MLS

$\square$ Master's degree(s) in nonlibrary field(s)

$\square$ JD

$\square \mathrm{MD}$ 
$\square \mathrm{PhD}$

$\square \quad \mathrm{EdD}$

$\square$ DBA

$\square \quad$ Other (please describe):

9. Have your degrees prepared you to be successful in the position that you currently hold?

$\square \quad$ Definitely yes

Probably yes

$\square$ Might or might not

$\square \quad$ Probably not

$\square \quad$ Definitely not

10. Why or why not? Please describe how your degrees have contributed to or hindered your success in the position you currently hold.

11. Reflecting on your career path: was it necessary for you earn an additional degree or degrees in order to achieve your highest library administrator position?

$\square$ Yes

$\square \quad$ No

\section{Notes}

1. Kathy Rosa and Kelsey Henke, 2017 ALA Demographic Survey, available online at www.ala.org/tools/ sites/ala.org.tools/files/content/Draft\%20of\%20Member\%20Demographics\%20Survey\%2001-11-2017.pdf [accessed 8 May 2018].

2. William L. Cohn, "An Overview of ARL Directors, 1933-1973," College E Research Libraries 37, no. 2 (1976): 140.

3. Cohn, "An Overview of ARL Directors, 1933-1973," 143.

4. Jerry L. Parsons, "How Have They Changed? Characteristics of Research Library Directors, 1958 and 1973," Wilson Library Bulletin 50, no. 8 (Apr. 1976): 614.

5. Parsons, "How Have They Changed?" 614.

6. Cohn, "An Overview of ARL Directors, 1933-1973," 141.

7. Cohn, "An Overview of ARL Directors, 1933-1973," 141.

8. Barbara B. Moran, "Career Patterns of Academic Library Directors," College \& Research Libraries 44, no. 5 (1983): 335.

9. Moran, "Career Patterns of Academic Library Directors," 334.

10. Moran, "Career Patterns of Academic Library Directors," 340.

11. Terrence F. Mech, "Small College Library Directors of the Midwest," Journal of Academic Librarianship 11 (1985): 9.

12. Rush G. Miller, "The Influx of PhDs into Librarianship: Intrusion or Transfusion?" College E Research Libraries 37, no. 2 (1976): 158-65.

13. Albert F. Maag, "Design of the Library Director Interview: The Candidate's Perspective," College E Research Libraries 41, no. 2 (1980): 112-21.

14. John N. Olsgaard and Jane Kinch Olsgaard, "Post-MLS Educational Requirements for Academic Librarians," College \& Research Libraries 42, no. 3 (1981): 224.

15. Olsgaard and Olsgaard, "Post-MLS Educational Requirements for Academic Librarians," 226.

16. Parsons, "How Have They Changed?" 613-17.

17. Cohn, "An Overview of ARL Directors, 1933-1973," 137-44.

18. Paul Metz, "Administrative Succession in Academic Libraries," College \& Research Libraries 39, no. 5 (1978): 358-64.

19. Olsgaard and Olsgaard, "Post-MLIS Educational Requirements for Academic Librarians," 227.

20. Moran, "Career Patterns of Academic Library Directors," 334-44.

21. Karen A. Hatcher, "Succession Paths for Academic Library Directors," in The Academic Library Director: Reflections on a Position in Transition, ed. Frank D'Andraia (New York: Routledge, 1997), 38-39. 
22. Hatcher, "Succession Paths for Academic Library Directors," 38-39.

23. Hatcher, "Succession Paths for Academic Library Directors," 38.

24. Peter McCracken, "The Presence of the Doctorate among Small College Library Directors," College $\mathcal{E}$ Research Libraries 61, no. 5 (2000): 401.

25. McCracken, "The Presence of the Doctorate among Small College Library Directors," 404.

26. Julie O'Keefe, "Small College Library Directors: Getting in the Door and Surviving on the Job," College $\mathcal{E}$ Research Libraries 59, no. 2 (1998): 139-52.

27. Rhonda Huisman, "Lifelong Learning: Moving beyond the Library Degree," College \& Research Libraries News 72, no. 5 (2011): 289.

28. Huisman, "Lifelong Learning," 289.

29. Huisman, "Lifelong Learning," 289.

30. Kathleen E. Aufderhaar, "Educational Requirement beyond the MLS for Academic Librarians in 1990" (master's dissertation, Kent State University), 1991.

31. Lee A. George and Julia C. Blixrud, "Systems and Procedures Exchange: The MLIS Hiring Requirement" (Chicago, IL: Association of Research Libraries, 2000).

32. Peter Hernon, Ronald R. Powell, and Arthur P. Young, "University Library Directors in the Association of Research Libraries: The Next Generation, Part One," College \& Research Libraries 62, no. 2 (2001): 122.

33. Hernon, Powell, and Young, "University Library Directors in the Association of Research Libraries," 122.

34. Ibid., 130.

35. Ibid., 130.

36. Ibid., 130.

37. Ibid., 130.

38. David W. Lewis, "Academic Library Staffing: A Decade from Now," in The Expert Library: Staffing, Sustaining, and Advancing the Academic Library in the 21st Century, eds. S. Walker and K. Williams (Chicago, IL: Association of College \& Research Libraries, 2010), 15.

39. Lewis, "Academic Library Staffing," 16.

40. Lewis, "Academic Library Staffing," 17.

41. Maggie Farrell, "The Lifecycle of Leadership," Journal of Library Administration 53 (2013): 256.

42. Farrell, "The Lifecycle of Leadership," 256.

43. Anja Smit, "'I Can't Look at Hobbles and I Can't Stand Fences': The Evolving Education Needs for Libraries," Charleston Voices (2018), available online at https:/against-the-grain.com/2018/03/charleston-voices-a-newseries-edited-by-matthew-ismail/ [accessed 23 July 2019].

44. Marta L. Brunner, "PhD Holders in the Academic Library: The CLIR Postdoctoral Fellowship Program," in The Expert Library: Staffing, Sustaining, and Advancing the Academic Library in the 21st Century, eds. S. Walker and K. Williams (Chicago, IL: Association of Research Libraries), 158-89. 